\title{
Tax Administration Act: Fulfilling human rights through efficient and effective tax administration
}

\author{
Fareed Moosa* \\ BProc LLB LLM LLD \\ Head of the Department of Mercantile and Labour Law, University of the Western \\ Cape
}

\section{OPSOMMING}

\section{Die Wet op Belastingadministrasie}

Openbare finansies is noodsaaklik vir doeltreffende bestuur ter vestiging van wet en orde, vrede en voorspoed, fasilitering van die heropbou- en herontwikkeling van nasionale infrastruktuur, en die verstrek van toegang tot sosiale goedere. Doeltreffende en effektiewe belasting administrasie is 'n noodsaaklike pilaar van 'n moderne, demokratiese staat. Hierdie artikel toon dat die Belasting Administrasie Wet 28 van 2011, op die keper beskou, gemik is op die bevordering van die openbare belang. Die kern van sy doelstellings is om seker te maak die doelmatige en doeltreffende invordering van belasting geskied. Hierdie doel is versoenbaar met die Grondwetlike doel van doeltreffendheid in openbare administrasie waarvan belasting administrasie 'n integrale deel vorm. Verder is die doelstellings van die Wet op Belasting Administrasie konsekwent met die Wet op die Suid-Afrikaanse Inkomstediens, 34 van 1997 wat meld dat SARS se doelwit die effektiewe en doeltreffende invordering van belasting is. Die Wet op Belasting Administrasie bevorder sodoende die Grondwet se onderliggende doelstellings. Dit is duidelik sigbaar daarin dat hierdie Wet gerig is op die verseker van voldoende openbare hulpbronne vir gebruik in die openbare voordeel. Hoewel hierdie strewe 'n legitieme regeringsdoel is, bly elke bepaling in die Wet nogtans onderhewig aan 'n ondersoek van rasionaliteit en, dus, geldigheid.

\section{Introduction}

The Constitution, 1996 embodies the ideals bonding South Africans who must cohere and transcend their divisions to change the condition of peoples' lives by reconstructing a South African society dogged by corruption and maladministration in the public sector, as well as various social ills (such as, poverty and inequality). Section $7(2)$ of the Constitution obliges the State to "respect, protect, promote and fulfil" the

* This article is an extraction of the writer's LLD thesis titled "The 1996 Constitution and the Tax Administration Act 28 of 2011: Balancing efficient and effective tax administration with taxpayers' rights".

How to cite: Moosa 'Tax Administration Act: Fulfilling human rights through efficient and effective tax administration' 2018 De Jure $1-16$

http://dx.doi.org/10.17159/2225-7160/2018/v51n1al 
rights entrenched in the Bill of Rights. To do so necessitates that the government has sustained access to adequate finance. Financial constraints in the public treasury will hinder the State's ability to achieve social justice through the fulfilment of, inter alia, socio-economic rights. Unless the problem of strained governmental resources is overcome, the aspiration of a fully transformed society with human dignity, freedom and equality for all will have a hollow ring. ${ }^{1}$ Finances derived from taxes are, thus, crucial. Success of the social transformation project hinges on the efficiency and effectiveness of tax collection by the South African Revenue Service (SARS). Inadequacy in public finances will hamstring the South African government's ability to fulfil the human rights of its people which, in turn, will give rise to cries that the government is failing in its duty under the Constitution to perform all constitutional obligations "diligently and without delay" (s 237).

In view of the foregoing, the imposition of national taxes and the enforcement of prompt and honest payment thereof are matters of national importance. Proper tax administration maintains a regular income stream that will keep the government and its functionaries continuously liquid, solvent and operational. The level of tax collection is, thus, a critical determinant of the quantum of funds that can be mobilised for government measures aimed at transformation. Equipping tax administrators with adequate powers that give them bite to optimise tax collection, serves SA's national fiscal interest. To this end, the Tax Administration Act 28 of 2011 (TAA) is important. Whilst it vests SARS with various pre-existing legal and administrative powers, it also grants extraordinary new powers, some of which place SARS on a collision course with taxpayers' fundamental rights entrenched in the Bill of Rights. To defend their rights against onslaught and diminution, taxpayers affected by tax administration occurring in terms of the TAA may attack the validity of the TAA itself, or the TAA provisions that confer wide-ranging powers on SARS and/or other officials that limit taxpayers' rights.

\section{Problem statement and objective of the article}

South Africa's tax system is somewhat complex owing to its sprawling legislative infrastructure. Historically, each tax statute dealt with its own procedures, duties and remedies. This created high levels of duplication across statutes. Whilst some statutory provisions were identical, others differed to varying degrees. This caused confusion in interpretation and application that contributed to increased tax related disputes, thereby rendering tax administration more convoluted and expensive. In his 2005 Budget Review, the Minister of Finance announced that a single, comprehensive statute would be passed that eliminates this overlapping by aligning and consolidating generic administrative provisions

1 Azanian People's Organisation $v$ President of the Republic of South Africa 19964 SA 671 (CC) para 43. 
replicated in multiple tax statutes. ${ }^{2}$ This is the avowed rationale that motivated the enactment of the TAA. ${ }^{3}$ The scale of the legislative process to streamline complex, disparate tax provisions was enormous. The process lasted about seven years and included, inter alia, internal and external workshops with stakeholders, public consultation, and an external constitutional review. This is all part of an inclusive legislative process that reflects SA's mode of participatory democracy, a distinctive principle in SA's new national ethos arising from the Constitution. ${ }^{4}$

The TAA overhauled the landscape of tax administration. Section 4(1) thereof reads: "This Act applies to every person who is liable to comply with a provision of a tax Act (whether personally or on behalf of another person) and binds SARS." Since SARS must comply with obligations imposed by the TAA, S 4(1) rebuts the presumption of interpretation that a legislature does not intend to bind the state (or its organs). The TAA has 20 chapters, each covering a different aspect of tax administration. The TAA's overall structure resembles that of New Zealand's Tax Administration Act 166 of $1994 .^{5}$ The TAA introduces a step-by-step methodology which aligns the essential order of tax administration to the administrative life cycle of taxpayers. This is illustrated by its chapter headings, a relevant factor in purposive interpretation of statutes. ${ }^{6}$ The TAA contains innovative tax administration strategies geared to ensuring that tax collection occurs in an orderly, structured, efficient and effective way. These features characterise a credible tax system. They advance the cultivation of a tax compliance culture that, if realised, will foster enhanced tax collection beneficial to the fiscus and, thus, the public purse. The promotion of tax compliance is a central value of the TAA.

The TAA can only play a meaningful role in facilitating access to adequate revenue from taxation by the South African government if its provisions have sufficient bite. The problem is that a literature survey of publications dealing with the TAA reveals that none analyses its provisions with a view to determining the degree to which the TAA

2 For relevant excerpts from the 2005 Budget Review, see the Release of the Draft Tax Administration Bill for Second Round of Public Comment 1 available at http://www.sars.gov.za/Legal/TaxAdmin/Pages/History.aspx (accessed 2809-2013).

3 For the background to the TAA, see Croome and Olivier Tax Administration (2015) 3-10.

4 See Doctors for Life International v Speaker of the National Assembly 20066 SA 416 (CC) para 115; Matatiele Municipality $v$ President of the Republic of South Africa (No.2) 20076 SA 477 (CC) paras 40 97; Merafong Demarcation Forum v President of the Republic of South Africa 20085 SA 171 (CC) para 44. Also, see Quinot "Snapshot or participatory democracy? Political engagement as fundamental human right" 2009 SAJHR 392; Seforo "Get in the game - taxpayer involvement in the drafting of a reasonable tax law" 2014 Tax Talk 62; Phooko "What should be the form of public participation in the lawmaking process? An analysis of South African cases" 2014 Obiter 39.

5 For a discussion of tax administration in New Zealand, see Alston “Taxpayers" rights in New Zealand" 1997 Revenue LJ 211.

6 Botha Statutory Interpretation: An Introduction for Students (2010) 80. 
succeeds in achieving the aims of, on the one hand, simplifying tax administration by SARS, and, on the other, ensuring that taxes are administered efficiently and effectively for public benefit. The objective of this article is to investigate this issue. To this end, the discussion commences by outlining the TAA's provisions that reveal its practical impact and statutory purpose. This discussion is important as it lays the foundation for purposive interpretation of the TAA and those terms therein that are discussed in this article. Secondly, the terms 'administration of a tax Act' and 'taxpayer' will be analysed within their TAA context. These terms are selected because they play central roles in tax administration under the TAA. Thirdly, tax collection under the TAA will be discussed. Finally, the conclusion will draw together the threads of the ensuing discussion.

\section{Impact of the TAA}

SARS and certain of its office bearers are creatures of statute. As such, they can perform no function and exercise no power unless authorised to do so by an enabling statute. ${ }^{7}$ The TAA is a source of such power. It confers wide-ranging audit, investigative and general legal and administrative powers. Certain of these powers (such as warrantless inspection and searches) have the potential of encroaching on taxpayers' fundamental rights to, for example, privacy and property. The TAA imposes obligations on SARS and its officials ${ }^{8}$ and outlines procedures ${ }^{9}$ to be followed. SARS officials must ensure that tax returns and declarations are timeously received and processed promptly, and that tax liabilities are assessed accurately and collected expeditiously. This requires tax capacity, that is, the ability to collect taxes efficiently and effectively. Errors in filing tax returns, auditing capacity and tax morality are some of the practical considerations that adversely affect the level of tax assessment and collection. Thus, it is imperative that SARS, in addition to employing adequate and competent staff, must be conferred powers that sharpen its bite so that it may achieve optimal tax compliance.

The TAA bolsters the efficiency and effectiveness of tax administration by catering for, inter alia, the issuing of identity cards to SARS officials (s 8(1)), the recognition of a deemed or presumed authority by SARS

7 See AM Moolla Group Ltd v CSARS 2005 JOL 15456 (T) 3.

8 For example, ss 42 (keeping taxpayers informed of audit completion), 69 (preservation of secrecy of taxpayer information), 82(2) (advance rulings are binding on SARS), 91-96 (duty to issue and give notice of a tax assessment), 106 (duty to decide a valid objection), 190 (duty to pay refunds), 207 (reporting of tax debts written off or compromised), and 216218 (duty to remit a penalty).

9 For example, ss 50 (process for obtaining prior authorisation for inquiry proceedings), 59 (process for warrant application), 172 (application for a civil judgment pending objection and appeal), 199 (procedure for writing off a tax debt), 204 (procedure for compromise of a tax debt), and 214 (procedure for imposing an administrative non-compliance penalty). 
officials in civil proceedings (s 11(2)), ${ }^{10}$ the granting of a right of appearance to a senior SARS official in certain judicial proceedings (s 12), the creation of the Tax Ombud to address taxpayer complaints (ss 1521 ), the confidentiality of taxpayer information (ss 67-74), the issuing of advance tax rulings (ss 75-90) and tax assessments (ss 91-100), the imposition of a more onerous burden of proof (s 102(1)), ${ }^{11}$ the objection and appeal procedures (ss 104-107), the Tax Court's jurisdiction (s 117), the application for a civil judgment to recover taxes (s 172), the payment of refunds (ss 190-191), the service of documents electronically (s $251(d)$ ), the granting of tax relief under a voluntary disclosure program (ss 225-233), the imposition of criminal sanctions for non-compliance with a 'tax Act' (ss 234-238), the registration of tax practitioners entitled to practise, and the reporting of unprofessional conduct on their part (ss 239-243), and the issuing of tax clearance certificates (s 256).

The TAA strengthens SARS's arsenal of powers by conferring authority on it, inter alia, to conduct audits and criminal investigations (s 41), to conduct inspections (s 45), to request 'relevant material' (s 46), to convene inquiry proceedings (ss 50-58), ${ }^{12}$ to oblige taxpayers to answer questions at an inquiry even if an answer is self-incriminating (s 57), to apply for search warrants (s 59), to conduct warrantless searches of the taxpayer's person, taxpayer's business premises and such part of a residence used for trade purposes (ss 61,63), to seize relevant material found during a search (s 61(3)), to issue jeopardy assessments (s 94), to institute sequestration, liquidation and winding-up proceedings in a court (s 177), to collect a tax debt from a third party who pays it on a taxpayer's behalf (ss 179-184), to provide assistance to foreign governments under an international tax agreement (s 185), to prevent taxpayers from trading whilst owing a tax debt (s 186(3)), to obtain a court order for the repatriation of a taxpayer's foreign assets (s 186), and to impose noncompliance penalties (ss 208-220) and understatement penalties (ss 221 224).

\section{Purpose of the Tax Administration Act}

Purposive interpretation of the TAA requires that effect be given to its overall purpose as is determinable from various objective factors apparent ex facie the statute. ${ }^{13}$ These include, inter alia, the language of its provisions, its long and short titles, its preamble, and its aims as set forth in $\mathrm{s} 2$ of the TAA. Curbing tax minimisation is incontestably a mischief at which certain TAA provisions are aimed (such as, s 94 and s 95 dealing with the issuing of jeopardy and estimated assessments

10 CSARS v Brown (unreported case no. 561/2016) 2016 ZAECPEHC 17 (5 May 2016) paras 19-21.

11 For the legal test to be applied when determining if a taxpayer has discharged an evidential onus, see CSARS v Kluh Investments (Pty) Ltd 2016 2 All SA 317 (SCA) para 9.

12 See Huang v CSARS: In re CSARS v Huang 20151 SA 602 (GP).

13 Natal Joint Municipal Pension Fund v Endumeni Municipality 20124 SA 593 (SCA) paras 18-20. 
respectively). However, the TAA's overall scheme is to harmonise (or synchronise) tax administration across a litany of tax statutes so as to improve the efficiency in, and effectiveness of, tax collection. Whilst the short title of the TAA indicates firmly that tax administration is its core subject matter, its long title affirms the overall objective of the statute. The relevant extract from the long title reads as follows: ${ }^{14}$

To provide for the effective and efficient collection of tax; to provide for the alignment of the administration provisions of tax Acts and the consolidation of the provisions into one piece of legislation to the extent practically possible; to determine the powers and duties of the South African Revenue Service and officials ... .

Section 2 of the TAA is a purpose clause that expresses the statute's objectives. It reads:

The purpose of this Act is to ensure the effective and efficient collection of tax by -

(a) aligning the administration of the tax Acts to the extent practically possible;

(b) prescribing the rights and obligations of taxpayers ${ }^{15}$ and other persons ${ }^{16}$ to whom this Act applies;

(c) prescribing the powers and duties of persons engaged in the administration of a tax Act; and

(d) generally giving effect to the objects and purposes of tax administration.

The content of ss 2(a) to (d) are not aims per se. They outline, in general terms, the means chosen by Parliament to give effect to a stated aim. The

14 For the use of a statute's long title as an aid in interpretation, see Bertie van Zyl (Pty) Ltd v Minister of Safety and Security 20102 SA 181 (CC) para 43.

15 Taxpayers' duties include, inter alia, (i) to register for tax (s 22); (ii) to communicate any change of particulars (s 23); (iii) to be honest by submitting 'full and true' and 'accurate' returns (ss 25, 27, 96(3)); (iv) to submit a certificate or statement supporting financial statements or accounts (s28); (v) to keep records for certain prescribed periods (ss 29, 30, 31, 32); (vi) to make a translation of a document when called upon to do so (s 33(1)); (vii) disclose information concerning a reportable arrangement (s 38); (viii) to attend an interview with SARS and be subjected to questioning (s 47); (ix) to attend and answer questions at an inquiry even if the answers are incriminating (s 57); (x) not to obstruct or refuse reasonable assistance to SARS officials executing a search and seizure warrant (s 61(7)); (xi) to disclose incriminating information in returns (s 72); (xii) to prove an entitlement to a deduction or exemption (s 102(1)); and (xiii) to give security for tax liability when called upon to do so by SARS (s 161).

16 The duties of third parties include, inter alia, (i) to submit full and true returns (ss 26, 27); (i) to keep records pertaining to a taxpayer's affairs (ss $29,30,31,32)$; (iii) to attend an inquiry and answer questions even if the answers are incriminating (s 57); (iv) not to obstruct or refuse reasonable assistance in the carrying out of a warrant by SARS (s 61(7)); and (v) to pay taxes for a taxpayer (Ss 154,157, 159, 179, 180, 181, 182, 183, 184). 
use of "and" between sub-paras (c) and (d) indicates that sub-paras (a) to (d) are to be read conjunctively (that is, not disjunctively). ${ }^{17}$ Recurring reference is made in sub-paras (a), (c) and (d) to tax administration. This fact lends credence to the construction that improved tax administration is the key method selected by Parliament for giving effect to its ultimate aim in the TAA of ensuring "the efficient and effective collection of tax".

The TAA (s 2(b)) refers to "prescribing the rights ... of taxpayers". Parliament's choice of "prescribing" taxpayers' rights as a means to give effect to the statute's aims is significant for various reasons. First, it underscores the legal culture of rights established by the Constitution. By "prescribing" rights for taxpayers, Parliament has imposed a corresponding duty on SARS and its officials to respect those rights. Secondly, s 2(b) highlights that respect for rights is a means chosen by Parliament for promoting efficiency and effectiveness in tax collection. This is a relevant value to be considered when a TAA provision is reviewed for constitutional congruence. Also, it reinforces the notion that a deeper culture of voluntary tax compliance will be established if SARS and its officials conduct themselves within the bounds of the law. Respect for the law, as well as for taxpayers and their rights fosters respect for SARS and its officials and breeds respect by taxpayers for their obligations arising from tax statutes. This, in turn, has the potential to create a tax environment that is less adversarial and more cooperative, dignified and respectful as between taxpayers and SARS officials. The creation of such environment accords with the values and ethos of the Constitution.

\section{Meaning of 'administration of a tax Act' analysed}

The process of tax administration is a natural consequence flowing from the imposition of a tax. In a broad sense, tax administration involves the formulation and development of tax policies underpinning domestic revenue laws and international tax treaties, as well as the administration, management, conduct and supervision of the execution and application of tax laws, policies and agreements. ${ }^{18}$ This includes, inter alia, information gathering and sharing, tax audits, assessment, collection, enforcement and litigation. ${ }^{19}$ Tax administration is a concept used in the TAA in a technical, legal sense. Section 3(2) provides a definition of "[a]dministration of a tax Act".

17 See Maphango v Aengus Lifestyle Properties (Pty) Ltd 20123 SA 531 (CC) para 50.

18 Stiglingh (ed), Koekemoer and van Zyl et al Silke: South African Income Tax 2016 (2015) 1134 define 'tax administration' as 'the process under which a person registers for a specific tax, submits relevant returns or information, retains prescribed documentation, is assessed for the tax and makes payment of the amount assessed'. In this narrow sense, tax administration serves merely as a means to audit a set of tax laws and "carries out the orders' of tax policy (see Mansfield 'Tax administration in developing countries: An economic perspective' 1988 Staff Papers IMF 181 183).

19 For a list of standard or usual functions included in tax administration, see Granger Economics Topic Guide: Taxation and Revenue (January 2013) 23-24. 
Tax administration is the key subject of the TAA. In terms of s 3(2), "[a]dministration of a tax Act means to", inter alia, (i) obtain full information; (ii) ascertain whether a person has filed or submitted correct returns, information or documents as required by a tax Act; (iii) establish a person's identity for the purpose of determining a tax liability; (iv) determine a tax liability; (v) collect taxes and refund taxes overpaid; (vi) investigate whether a tax related criminal offence has been committed pursuant to the provisions of a tax Act and, if so, lay criminal charges and provide assistance for the investigation and prosecution of tax offences or related common law offences; (vii) enforce SARS's powers and duties under a tax Act to ensure tax compliance; (viii) perform any other administrative function necessary to carry out the provisions of a tax Act; and (ix) give effect to SA's obligation to provide assistance under an international tax agreement. ${ }^{20}$

From the foregoing, it is evident that s 3(2) crystallises the different components involved in tax administration and amplifies the scope and ambit of the terms used in s 2 quoted above. Section 3(2) gives form and substance to the phrase "administration of a tax Act" used in s 2(c) and enhances an understanding of "objects and purposes of tax administration" as used in s 2(d). Accordingly, s 2 and s 3(2) must be read in conjunction with, and not independent of, each other. In terms of $\mathrm{s}$ 3(2), "administration of a tax Act" is a formal process encapsulating a broad spectrum of functions, duties and powers to be performed by SARS in relation to the affairs of a 'taxpayer', the definition whereof is discussed below. Tax collection is but a single element of this process. Tax administration under the TAA is, thus, not confined to recovering unpaid taxes. Section 3(2) is couched in terms having broad strokes (or effect). It extends to various associated or ancillary activities aimed at enhancing the efficiency and effectiveness of tax collection.

The intended scope of a definition may be determined by parameters imposed in its text. The definition in s 3(2) is introduced by the word 'means' which, generally, indicates that the definition following it is comprehensive and all-encompassing (that is, complete, fixed, finite).$^{21}$ Nothing more can be read into it. On this basis, ss 3(2)(a) - (i) appears to contain a closed list of activities comprising tax administration. However, s 3(2)(h) opens up the list by empowering SARS to "perform any other

20 A discussion of the individual components of the tax administration process (such as, tax registration, submission of returns, maintenance of records, issuing of tax assessments, objections and appeals), falls beyond the scope of this article and is, therefore, not undertaken here.

21 See Warwick Investments (Pty) Ltd $v$ Maharaj 19542 SA $470(\mathrm{~N})$; Rogut $v$ Rogut 19823 SA 928 (A); Southern Life Association Ltd v CIR 19852 SA 267 (C) 269-270; S v Tshilo 20004 SA 1078 (CC) para 9; Birkenruth Estates (Pty) Ltd $v$ Unitrans Motors (Pty) Ltd 20053 SA 54 (W); S v Dzukuda; City of Tshwane v Marius Blom 20133 All SA 481 (SCA) para 12. 
administrative function necessary to carry out the provisions of a tax Act'. 'Any' is a word of wide import and unqualified generality. ${ }^{22}$ Its effect is that all things related to its subject are covered by the provisions to which it relates, except things restricted by its subject matter or context. 'Any' casts wide the functions falling within the ambit of $s$ $3(2)(h)$. Thus, SARS is empowered to perform a range of functions not expressly listed in s 3(2). This construction fits naturally with, first, the inclusion in the South African Revenue Service Act 34 of 1997 (s 5(1)(j)) of SARS's power to engage in "any activity, ... to promote proper, efficient and effective tax administration". Secondly, the construction contended for here is also consistent with $\mathrm{s} 5(1)(\mathrm{k})$ of that Act which empowers SARS to "do anything that is incidental to the exercise of any of its powers". In the context of sS 5(1)(j) and (k) respectively, 'any' and 'anything' casts extremely widely SARS's intended authority.

Accordingly, SARS's powers are not confined to a closed list of functions enumerated in s 3(2). SARS is empowered to perform 'any' such other administrative function which is necessary to carry out the provisions of a 'tax Act'. Hoexter ${ }^{23}$ states that implied powers may be ancillary to the express powers granted to an administrator, or may exist either as a necessary or reasonable consequence of the express powers conferred on any such decision maker. Therefore, according to Hoexter, "what is reasonably incidental to the proper carrying out of an authorised act must be considered as impliedly authorized".

The TAA (s 3(2)(h)) prescribes that SARS's authority to act is subject to the requirement that the function performed is 'administrative' and 'necessary'. These words are undefined in the TAA. It is a trite principle of interpretation that statutory words are to be interpreted textually, contextually, purposively and teleologically. ${ }^{24}$ A statutory word must bear its primary meaning, unless cogent internal indications point to it meaning something else. ${ }^{25}$ An 'administrative' act entails conduct that implements or gives effect to a policy, legislation or an adjudicative decision. ${ }^{26}$ The adjective 'necessary' admits of various degrees of comparison. It is not synonymous with 'indispensable', neither does it have the flexibility of such expressions as 'admissible', 'ordinary',

22 See Southern Life Association Ltd v CIR 198447 SATC 15 (C) 18-19; CIR v Ocean Manufacturing Ltd 19903 SA 610 (A) 618; Commissioner for Customs and Excise v Capital Meats CC (in liquidation) 199961 SATC 1 (SCA) 5; Body Corporate of Greenacres v Greenacres Unit 17 CC 20083 SA 167 (SCA) para 5; ARMSA $v$ President of the Republic of South Africa 20137 BCLR 762 (CC) paras 33-35.

23 Hoexter Administrative Law in South Africa (2012) 43-44. See also Potwana v University of KwaZulu-Natal 2014 JDR 0156 (KZD) para 34.

24 An interpreter must strike a fair balance between the language of a text and the context of the provision being interpreted. See Bertie van Zyl supra para 46.

25 Northwest Townships (Pty) Ltd $v$ Administrator, Transvaal 19754 SA 1 (T) 12.

26 Grey's Marine Hout Bay (Pty) Ltd v Minister of Public Works 20056 SA 313 (SCA) para 24. See also Hoexter The New Constitutional \& Administrative Law (2002) 28. 
'useful', 'reasonable' or 'desirable'. ${ }^{27}$ The Concise Oxford Dictionary ${ }^{28}$ defines 'necessary' to mean "needed to be done, achieved, or present; essential requiring to be done, essential, needed for a purpose". Thus, 'necessary' connotes a pressing need. It is often connected with a word increasing or decreasing the impression of urgency. Thus, a thing may be necessary, very necessary, reasonably necessary, absolutely or indispensably necessary. ${ }^{29}$ In such instances, the meaning of 'necessary' is coloured by the word with which it is associated.

For the purposes of s 3(2)(h), 'necessary' must satisfy the touchstone of reasonableness. Thus, a function falls within the contemplation of this provision if its performance is 'reasonably necessary' to realise "the ostensible legislative intention or to make the statute workable". 30 The question of necessity is a factual issue to be decided with reference to the fiscal interests or needs served by the performance of a particular function. Whenever SARS seeks to invoke the administrative function, it bears the onus to prove that the necessity precondition is met. 31

\section{Meaning of 'taxpayer' analysed}

An analysis of the definition of 'taxpayer' in the TAA is significant for various reasons. First, unpacking its meaning enhances an understanding of taxpayers potentially subject to SARS's authority under the TAA read with s 4(1)(a) and Schedule 1 of the South African Revenue Service Act. Secondly, the definition of 'taxpayer' demarcates the scope and ambit of this term in the TAA (s 2(b)) in the context of the phrase 'the rights and obligations of taxpayers ... to whom this Act applies'. Thirdly, an understanding of its meaning sheds light on the categories of persons who, as taxpayers, are potential claimants of fundamental rights in the Bill of Rights that are relevant during tax administration. The TAA (s 1 read with s 151) defines 'taxpayer' as 'means - (a) a person chargeable

27 Mpande Foodliner CC v CSARS 20004 SA 1048 (T) 1064C.

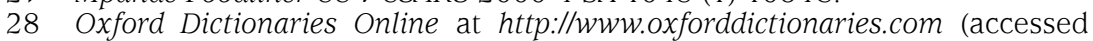
23-02-2014).

29 McCulloch v Maryland 18194 Wheat. 316 414. For the test for 'necessary', see Van der Merwe $v$ Randryk Beleggings (Edms) Bpk 19762 SA 414 (O); KBI $v$ Van der Walt 19864 SA 303 (T) 308. See also de Ville 'Guidelines for judicial reviews on "division of powers" grounds' 1995 Stell LR 139 153; Moosa 'The scope of the expression "necessarily incurred" in section 18(1) of the Income Tax Act' 2013 SA Merc LJ 184194.

30 Masetlha $v$ President of the Republic of South Africa 20081 SA 566 (CC) para 192. See also Berg River Municipality v Zelpy 2065 (Pty) Ltd 20134 SA 154 (WCC) para 28.

31 For a discussion of onus in tax matters under the TAA, see Goldswain The Winds of Change- An Analysis and Appraisal of Selected Constitutional Issues Affecting the Rights of Taxpayers (Doctor of Accounting Science dissertation 2012 UNISA) 105-119. 
to tax; (b) a representative taxpayer; ${ }^{32}$ (c) a withholding agent; ${ }^{33}$ (d) a responsible third party; ${ }^{34}$ or (e) a person who is the subject of a request to provide assistance under an international tax agreement". 35 This definition encompasses natural and juristic persons, including persons located outside of South Africa's territorial borders. Section 151(e) applies to a 'taxpayer' who is liable for a foreign tax debt to a foreign government. In terms of the TAA, SARS may recover such debt by cooperating with a foreign tax authority. To this end, SARS may take steps under s 185 of the TAA ${ }^{36}$ to recover the debt from assets located in South Africa that are owned by the taxpayer or in which the taxpayer has a legal interest.

Whilst registration or incorporation is a legal requirement for the de jure existence of certain statutory juristic persons (for example, companies and close corporations), it is not a legal requirement for a natural or juristic person to be a taxpayer. Although the TAA (s 22) provides for taxpayer registration, this is not a legal pre-requisite to be a taxpayer. For example, a minor is, strictly speaking, a taxpayer by virtue of paying tax (such as value-added tax) on the purchase of any item (such as sweets). For TAA purposes, a person is ex lege a 'taxpayer' as defined from the moment he/she/it is caught in the web of a taxing statute. Registration as a 'taxpayer' is but a formality that is necessary to formalise and regularise a taxpayer's fiscal affairs in circumstances where the TAA or other tax law demands that registration occurs. Therefore, taxpayer registration is simply a confirmation of a pre-existing legal fact or state of affairs. Registration does not create or confer the 'taxpayer' status on anyone. This is clear from the fact that taxpayer registration does not apply to all taxpayers or for all taxes governed by

32 The TAA (s 153(1)) defines 'representative taxpayer' to mean "a person who is responsible for paying the tax liability of another person as an agent, other than as a withholding agent, and includes a person who $-(a)$ is a representative taxpayer in terms of the Income Tax Act; $(b)$ is a representative employer in terms of the Fourth Schedule to the Income Tax Act; or $(c)$ is a representative vendor in terms of section 46 of the ValueAdded Tax Act".

33 The TAA (s 156) defines 'withholding agent' to mean "a person who must under a tax Act withhold an amount of tax and pay it to SARS".

34 The TAA (s 158) defines 'responsible third party' to mean "a person who becomes otherwise liable for the tax liability of another person, other than as a representative taxpayer or as a withholding agent, whether in a personal or representative capacity".

35 The TAA (s 155, s 157, s 159) provides that the taxpayers mentioned in subparas $(b),(c)$ and $(d)$ of $s 151$ are personally liable for the tax debt otherwise payable by their (tax) principals. For a discussion of the term 'taxpayer' in the TAA, see Clegg LexisNexis Concise Guide to Tax Administration (2012) 86. For an interpretation of 'taxpayer' generally, see CSARS $v$ van Kets 201274 SATC 9

36 The TAA (s 185) empowers SARS to recover a foreign tax debt by levying execution against the local assets of a foreign tax debtor found in SA. This SARS may do if it acts in terms of an 'international tax agreement' defined in $\mathrm{S} 1$ as including "an agreement entered into with the government of another country in accordance with a tax Act". See Krok v CSARS 20156 SA 317 (SCA). 
the TAA. For example, a land purchaser who is liable for transfer duty under the Transfer Duty Act 40 of 1949, and a deceased estate liable for estate duty under the Estate Duty Act 45 of 1955, are not required to register for these fiscal purposes. Likewise, all recipients of goods or services are obliged to pay VAT to a supplier registered as a vendor under the Value-Added Tax Act 89 of 1991. This Act does not require a payer of VAT to register as a taxpayer to be liable for payment of such tax. Any payer of transfer duty, estate duty and VAT is a 'taxpayer', stricto senso.

\section{Tax collection under the Tax Administration Act}

The TAA (s 3(2)(e)) incorporates tax collection as a core facet of tax administration. It is in the public interest that taxes are collected. ${ }^{37}$ Tax collectors are the engines driving a state's effort to swell the public treasury. Tax collection must occur in a principled way consistent with the Constitution and an enabling statute. The rule of law, a founding constitutional value, prohibits arbitrariness in tax collection and precludes financial considerations being used to justify an infringement of entrenched rights. ${ }^{38}$ Thus, for example, SARS cannot require taxpayers to pay more tax than is due in law, nor can it claim taxes in advance of their due dates. ${ }^{39}$ No tax may be collected unless there is a tax debt due and payable as determined in accordance with a statute. ${ }^{40}$ No tax liability arises unless a taxpayer is brought within the reach of a legislative text expressing the legislature's will. ${ }^{41}$ A tax liability arises when a taxable event ${ }^{42}$ occurs, the nature whereof is determined by a taxing statute. For example, an income tax liability is regulated by the definition of 'taxable income' of which 'gross income' is an integral part. ${ }^{43}$ The gross income of a 'resident' (as defined) means 'the total

37 CSARS v Brummeria Renaissance (Pty) Ltd 20076 SA 601 (SCA) para 26.

38 Schachter $v$ Canada [1992] 2 SCR 679 709. See also Brand 'Financial constitutional law - a new concept in South Africa?' 2008 TSAR 8997.

39 See Deak 'Taxpayer rights and obligations: The Hungarian experience' 1997 Revenue LJ 1819.

40 The TAA (s 1 read with s 169(1)) defines 'tax debt' to mean "an amount of tax due or payable in terms of a tax Act". 'Tax' is defined in s 1 as including a "penalty" and "interest". A tax debt is 'due' when there is a "liquidated money obligation presently claimable by the creditor for which an action could presently be brought against the debtor. Stated another way, the debt must be one in respect of which the debtor is under an obligation to pay immediately". See Singh v CSARS 20034 SA 520 (SCA) para 25. For a discussion of the distinction between taxes 'due' from those 'payable', see Namex (Edms) Bpk v KBI 19942 SA 265 (A) 289; Capstone 556 (Pty) Ltd v CSARS; Kluh Investments (Pty) Ltd v CSARS 20116 SA 65 (WCC) para 13.

41 Welch's Estate $v$ CSARS 20054 SA 173 (SCA) para 89.

42 The TAA (s 1) defines 'taxable event' to mean "an occurrence which affects or may affect the liability of a person to tax".

43 For the definitions of 'taxable income' and 'gross income', see s 1 of the Income Tax Act 58 of 1962. For an analysis of these terms, see CIR $v$ Nemojim (Pty) Ltd 19834 SA 935 (A) 946. 
amount in cash or otherwise ${ }^{44}$ received by ${ }^{45}$ or accrued to ${ }^{46}$ or in favour of such resident ... excluding receipts or accruals of a capital nature'. ${ }^{4}$

A tax assessment is not a prerequisite for a tax liability. ${ }^{48}$ The TAA (s 1) defines 'assessment' to mean "the determination of the amount of a tax liability or refund, by way of self-assessment by the taxpayer or assessment by SARS". "Thus, its purpose is to compute a tax debt or refund due to a taxpayer. ${ }^{50}$ 'Assessment' is distinguishable from 'notice of assessment'. The latter, dealt with in the TAA (s 96), is not necessarily the same as the former. 51 Although the dictionary meaning of 'tax' includes an 'assessment', this meaning is not included in the definition of 'tax' in the TAA ( $\mathrm{s} 1$ ). This notwithstanding, if another 'tax Act' incorporates an 'assessment' as part of its meaning of 'tax', then such meaning would be covered by the TAA because the definitions clause in s 1 expressly stipulates that, for TAA purposes, "a term which is assigned a meaning in another tax Act has the meaning so assigned". Although a tax assessment is a "mental act in the nature of a decision", 52 generally no tax is recoverable through judicial intervention until after this mental act manifests itself outwardly in the form of a written assessment furnished to the taxpayer. ${ }^{53}$ This notification is a procedural pre-requisite for the lawful enforcement thereof by SARS. The TAA codifies this requirement. Section 172(1) thereof provides that once a tax debt is payable, "SARS may, after giving the person at least 10 business days' notice, file with the clerk or registrar of a competent court a certified statement setting out the amount of tax payable and certified by SARS as correct". Section 172(3) provides for a relaxation of this notice

44 For the meaning of 'amount', see CIR $v$ Butcher Brothers (Pty) Ltd 1945 AD 301; CIR $v$ Hersov 19521 SA 485 (A) 491-493; CSARS v Brummeria Renaissance (Pty) Ltd 20076 SA 601 (SCA) paras 11-19.

45 For the meaning of 'received by', see CSARS $v$ Cape Consumers (Pty) Ltd 19994 SA 1213 (C) 1221-1223.

46 For the meaning of 'accrued to', see CIR $v$ People's Stores (Walvis Bay) (Pty) Ltd 19902 SA 353 (A) 365A-367D; Cactus Investments (Pty) Ltd v CIR 19991 SA 315 (SCA) $320 \mathrm{H}$.

47 For the test to distinguish between capital and revenue income, see CSARS $v$ Founders Hill (Pty) Ltd 20115 SA 112 (SCA) paras 18-52; Stellenbosch Farmers' Winery Ltd $v$ CSARS; CSARS $v$ Stellenbosch Farmers' Winery Ltd 20125 SA 363 (SCA) paras 23-46; CSARS v Capstone 556 (Pty) Ltd 20162 All SA 21 (SCA) paras 22-32.

48 Namex (Edms) Bpk supra 289; Contract Support Services (Pty) Ltd v CSARS 199861 SATC 338351.

49 For the characteristics of an 'assessment', see First South African Holdings (Pty) Ltd v CSARS 201173 SATC 221 226E-F; CSARS v South African Custodial Services (Pty) Ltd 20121 SA 522 (SCA) paras 28-32. See also Moosa 'Letters and assessments: What is an income tax "assessment"?' 2012 Tax Planning 32.

50 CIR v Lazarus' Estate 19581 SA 311 (A) 326

51 Clegg 24.

52 Irvin \& Johnson (SA) Ltd v CIR 1946 AD 483494.

53 Singh supra para 15. 
requirement "if SARS is satisfied ${ }^{54}$ that giving notice would prejudice the collection of the tax".

It is impermissible for SARS to waive payment of any tax, unless it is authorised by law to do so. This principle of taxation, traceable to Collector of Customs $v$ Cape Central Railways $L t d,{ }^{55}$ is reinforced by S 4(1) of the South African Revenue Service Act which provides that SARS's function is to secure the widest possible enforcement of tax laws. Thus, it is incumbent on it to take all reasonably necessary steps to recover unpaid taxes. ${ }^{56}$ This principle also finds expression in the TAA. Section 143(1) thereof provides that "[a] basic principle in tax law is that it is the duty of SARS to assess and collect tax according to the laws enacted by Parliament and not to forgo a tax which is properly chargeable and payable". 57 Consequently, the TAA stipulates the following: (i) "[t]ax must be paid by the day and at the place notified by SARS, the Commissioner by public notice or as specified in a tax Act" (s 162(1)), and (ii) "[a]s a general rule, it is the duty of SARS to assess and collect all tax debts according to a tax Act and not to forgo any tax debts" (s 193(1)). Section 193(2) refers to this latter duty as "strict" and "rigid". Thus, the legislative scheme of the TAA is structured in a way that will ensure maximum collection of tax debts due to the fiscus. This is a legitimate governmental objective.

The duty on SARS to collect unpaid taxes applies strictly, except as is otherwise provided by law. The TAA (s 193(2)) permits SARS to "deviate from the strictness and rigidity of the general rule referred to in subsection (1) if it would be to the best advantage of the State" (my emphasis). The italicised words contain the prescribed jurisdictional fact $^{58}$ that is a precondition which must exist, and be shown to exist, when a decision is taken to deviate from the stipulated norm (or general

54 For the legal meaning of 'satisfied', see Breitenbach $v$ Fiat $S A$ (Edms) Bpk 19762 SA 226 (T) 228A-B; ITC 1470199052 SATC 88 92; Farjas (Pty) Ltd $v$ Regional Land Claims Commissioner, KwaZulu-Natal 19985 BCLR 579 (LCC) para 41. As regards proof of SARS's 'satisfaction', see Natal Estates Ltd $v$ CIR 19754 SA 177 (A) 208.

5518886 SC 402 405-406. See also CIR v The Master 19573 SA 693 (C) 701 702; AM Moolla Group Ltd v CSARS 2003 JOL 10840 (SCA) paras 18-20.

56 Therefore, SARS is not merely an organ of state dealing exclusively with the management of, and legislation relating to, revenue collection. See SARS $v$ Armsec Professional Services (Pty) Ltd 199866 SATC 277 (SECLD) 279.

57 This provision is comparable to $\mathrm{S} 6 \mathrm{~A}(3)$ of New Zealand's Tax Administration Act 166 of 1994.

58 The Court, in MEC for Health, Eastern Cape v Kirland Investments (Pty) Ltd 20143 SA 481 (CC) para 98, held: 'Jurisdictional facts refer broadly to preconditions or conditions precedent that [objectively] must exist before the [valid] exercise of power, and the procedures to be followed when exercising that power.' In tax administration, this often consists of the CSARS being satisfied of the existence of certain facts giving rise to a decision causing a "particular fiscal result". See ITC 1876201577 SATC 175 para 21. For a discussion of the role of jurisdictional facts in administrative law, see de Ville Judicial Review of Administrative Action in South Africa (2005) 156-162. 
rule) concerned. If it does not exist, then no valid deviation may take place. Under these circumstances, the administrative decision permitting the waiver of a tax debt, or any part thereof, may, on application by a competent SARS official, be judicially reviewed and set aside for illegality, irrespective of whether the objectionable decision was made in good faith or negligently. ${ }^{59}$ However, since such illegal act exists in fact, it gives rise to valid consequences until it is set aside by a court. ${ }^{60}$

The meaning of the phrase "to the best advantage of the State" is fleshed out in the TAA's requirements for the granting of a 'write off' and 'compromise' of a tax debt. Section 195(1)(a) of the TAA provides that a senior SARS official "may decide to temporarily "write off" an amount of tax debt if satisfied that the tax debt is uneconomical to pursue as described in section 196 at that time". Section 197(1) of the TAA provides that a senior SARS official "may authorise the permanent 'write off' of an amount of tax debt - (a) to the extent satisfied that the tax debt is irrecoverable at law as referred to in section 198; or (b) if the debt is "compromised' in terms of Part D". In terms of s 200 of the TAA, a senior SARS official "may authorise the 'compromise' of a portion of a tax debt upon request by a 'debtor', which complies with the requirements of section 201, if - (a) the purpose of the 'compromise' is to secure the highest net return from the recovery of the tax debt; and (b) the 'compromise' is consistent with considerations of good management of the tax system and administrative efficiency".

A taxpayer does not have a right or entitlement to a write-off or compromise of a tax debt. At best, there is a right to apply for this benefit. This right is useful where the duty to pay tax is, as in South Africa, not based on economic capacity or financial ability. ${ }^{61}$ Every compromise or write off application must be considered on its merit. The determination of its outcome amounts to administrative power to be exercised within constitutional limits, ${ }^{62}$ and subject to the dictates of procedural and substantive administrative fairness regulated by the Promotion of Administrative Justice Act 3 of 2000 read with the TAA (such as, prior notice of an intended decision, clear grounds for a

59 Merafong City v AngloGold Ashanti Ltd 20162 SA 176 (SCA) paras 15-17; Berg River Municipality v Zelpy 2065 (Pty) Ltd 20134 SA 154 (WCC) para 27.

60 Oudekraal Estates (Pty) Ltd $v$ City of Cape Town 20046 SA 222 (SCA) paras 26-31; Pikoli v President of the Republic of South Africa 20101 SA 400 (GNP) 408C-E. The Court, in Fose v Minister of Safety and Security 19973 SA 786 (CC) $834 \mathrm{~F}$, held that unconstitutional conduct is a nullity "even before Courts have pronounced it so". The Court held, in Bengwenyama Minerals (Pty) Ltd v Genorah Resources (Pty) Ltd 20114 SA 113 (CC) para 85, that the "anomaly that an unlawful act can produce legally effective consequences is not one that admits easy and consistently logical solutions. But then the law often is a pragmatic blend of logic and experience."

61 A contrary legal position appears in the Constitutions of Italy 1947 (Art 53) and Spain 1978 (Art 31). See Roch Tax Administration vs Taxpayer: A New

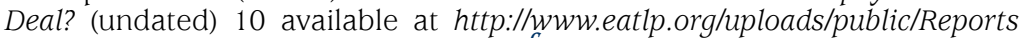
\% 20Rotterdam/Moessner \% 20lecture.pdf (accessed 01-04-2018).

62 Pharmaceutical Manufacturers Association of SA: In re Ex parte President of the Republic of South Africa 20002 SA 674 (CC) para 20. 
decision, and adequate notice of the right to request reasons for a decision) ${ }^{63}$ Every decision reached must constitute a legitimate exercise of public power. ${ }^{64}$ In terms of the TAA, a designated senior SARS official is responsible for ensuring the integrity of the process. In practice, however, decisions regarding compromise and write off applications are decided at a branch of SARS by a panel or committee of senior SARS officials. This ensures that a taxpayer's right to just administrative action is not illusory but remains real. The expressions 'may decide' and 'may authorise' confers a discretion that must not be exercised capriciously but with due regard to constitutional and general legal principles. ${ }^{65}$ All relevant facts and circumstances must be considered, including the reason for the conferral of the discretion. ${ }^{66}$ The decision taken must be rationally related to the purpose for which the power was granted. If not, then the decision taken is judicially reviewable on the grounds of arbitrariness and inconsistency with the rule of law.

\section{Conclusion}

Public finance is vital for enabling effective governance, maintaining law and order, promoting peace and prosperity, facilitating the reconstruction and redevelopment of national infrastructure, and providing access to social goods (such as, education and social security). Efficient and effective tax administration is an essential pillar of a modern, democratic state. This article shows that the TAA is unmistakably aimed at advancing the public interest. The kernel of its aims is ensuring the proper collection of tax. This purpose is reconcilable with the principle in the Constitution (s 195(1)) requiring efficiency in public administration, of which tax administration forms an integral part. Furthermore, the aims of the TAA are consistent with the South African Revenue Service Act (s 3) stating that SARS's objective is the "efficient and effective collection of revenue". In so doing, the TAA serve to enhance fulfilment of the Constitution's underlying goals. This is so because the TAA is geared towards ensuring the availability of adequate public resources for public benefit or use in the public interest. ${ }^{67}$ Though this pursuit is a legitimate governmental purpose, each provision in the TAA remains subject to scrutiny for rationality ${ }^{68}$ and, thus, validity.

63 For a discussion of fairness in administrative action, see Bengwenyama Minerals supra paras 69-70.

64 Van Eck and Van Rensburg $v$ Etna Stores 19472 SA 984 (A).

65 Dawood $v$ Minister of Home Affairs; Shalabi $v$ Minister of Home Affairs; Thomas $v$ Minister of Home Affairs 20003 SA 936 (CC) paras 47-56; Helen Suzman Foundation $v$ President of the Republic of South Africa; Glenister $v$ President of the Republic of South Africa 20152 SA 1 (CC) paras 182-183.

66 Northwest Townships (Pty) Ltd v Administrator, Transvaal 19754 SA 1 (T) 1213.

67 CSARS v Africa Cash \& Carry (Pty) Ltd 201577 SATC 242 (GNP) para 19.

68 UDM $v$ President of the Republic of South Africa 200211 BCLR 1179 (CC) para 55. 